\title{
Changes in the hydrothermal regime in the Central Black Earth region and the reaction of cultivated plants
}

\author{
Ludmila Grigoreva ${ }^{1 *}$, and Elena Tsukanova ${ }^{2 * *}$ \\ ${ }^{1}$ Federal State Budgetary Educational Institution of Higher Education «Michurinsk State Agrarian \\ University», 101 (3), International street, Michurinsk, 393760, Russia \\ ${ }^{2}$ Federal State Scientific Institution «I. V. Michurin Federal Scientific Center», 30 st. Michurina, \\ Michurinsk, 393770, Russia
}

\begin{abstract}
The analysis of changes in the water-temperature regime of the Central Black Earth region of Russia over the past 90 years is given. A significant increase in the dispersion of daily air temperatures and a change in the distribution of precipitation by months were noted. It has been established that the most significant limiting factor for fruit plants is currently the daily air temperature drops. The periods of the annual cycle are systematized according to the degree of damaging effect on fruit plants. It has been determined that the main tendency of changes in the hydrothermal regime on the territory of the Central Black Earth Region is its destabilization, i.e. increase of the frequency and amplitude of air temperature drops, and raise of the number of thaws in January-February. The increase of the discreteness of precipitation distribution within the year is possible - excessive moisture in some months (especially June, September, 2-3 decades of February - March) and aridity in others (July, August, November, December).
\end{abstract}

The degree of realization of the genotypically determined potential of agricultural plants in specific conditions is determined by abiotic factors and, first of all, by climatic ones. The productivity of plants is influenced by many factors, the main ones are solar activity, humidity, temperature, which, being within the optimum, are not stressors, however, any deviation from the norm (excess or deficiency) leads to negative consequences. Climatologists all over the world note a significant change in the climatic conditions of the earth in a biologically short period of time [1-2]. The Central Black Earth (CBE) Region was no exception. The aim of the research was to establish the most dangerous climatic factors for fruit plants based on the analysis of literature data and our own long-term observations of the reactions of fruit plants to changing weather conditions. At the same time, it was noted that the key climatic components for the life of cultivated plants are the hydrothermal regime of the cultivated area. The current trends in changes in climate characteristics (such as an intense increase in air temperature, climatic instability and an

\footnotetext{
* Corresponding author: grigorjeval@mail.ru

** Corresponding author: elenam31@yandex.ru
} 
increased frequency of recurrence of extreme weather conditions) are probably the result of the complex impact of the natural cyclical dynamics of climate and anthropogenic factors [1-4]. In addition, the amplitude increased and the frequency of the trend component of the amount of precipitation decreased, against the background of an increase in the average annual air temperature $[5,6]$. Nowadays, the complex effect of damaging climatic factors on fruit plants is more and more often noted, this is especially dangerous in conjunction with biotic ones. A well-grounded concern of farmers is caused by the drop in biological resistance of cultivated plants in recent years. The impact of a complex of unfavorable (stress) factors on fruit plants increases, in this regard, the resistance of agrocenoses sharply decreases, their susceptibility to damage by harmful organisms increases [7, 8]. In recent years, the loss of yield at various stages of its formation has been quite often observed. The foregoing determines the need for a detailed analysis of the main changes in the hydrothermal regime of the territory, determining the level of their stress for garden plants. This allows to establish the suitability for cultivation of a particular horticultural crop, as well as to determine the most suitable varieties for a given territory.

In our opinion, a significant change in the hydrothermal regime time is the most significant among the negative factors of nature nowadays, which leads to serious losses in the productivity of agricultural crops; this fact is confirmed by the analysis of weather conditions over the past 90 years. Based on the analysis of long-term data from the Michurinsk agrometeorological station (northern part of the CBE), we recorded significant climatic changes. The following years differed most strongly (in terms of weather conditions) from the average long-term values: 1990, 1994, 2000, 2004, 2006, and 2010. In these years, in a large territory of central Russia was noted a catastrophic state of plantations of fruit and berry crops, in which there was almost complete loss of the yield, and, in some cases, the death of plantings. [9].

Based on the previously conducted analytical studies of the dispersions of the annual air temperature from 1931 to 2020 , the daily dispersion of air temperatures, the variation of the annual humidity regime and the distribution of precipitation by months for the same period, we have reliably proved that the period from 1962 to 1970 is the most stable in terms of the hydrothermal regime, and, therefore, can serve as a certain control of the stability of weather conditions, with which it is most convenient to compare the hydrothermal characteristics of recent years. In addition, a significant destabilization of the above climatic characteristics has been identified, which has been significantly increasing in the last 2 decades, and its impact can only be mitigated by certain agricultural practices [8 $11]$.

It should be noted a significant increase in the stress of the hydrothermal regime in the most energy-consuming periods for garden plants - the beginning of the growing season, flowering and fruit setting, as well as entering and exiting the state of winter dormancy [8, 9].

A significant increase in the dispersion of daily temperatures was noted in OctoberNovember (1.1 relative units in 1960-1970 and 9.8 relative units in 2000-2020) and MarchApril (3.5 relative units. in 1960-1970 and 14.7 relative units in 2000-2020).

Thus, in our opinion, among the climatic characteristics studied by us, the greatest danger to fruit plants is currently represented by daily air temperature drops, as well as a combination of several types of stressors simultaneously $[8,12]$.

It should be noted that there are universal criterion signs that characterize the level of response of a plant organism to the impact of any stressor: the level of genotypic resistance of the variety, the location of the planting, the level of agro technical care, etc. This is primarily due to the fact that the balance of positive and negative impacts conditions the general physiological state of perennial fruit crops over many years of their life. The impact of stressors over a number of years leaves its mark on the physiological processes in plants. 
These negative stressors are constantly accumulating in plants. In this regard, the response to these stresses may appear in plants not necessarily immediately, but in the form of a response after a year or longer time, which can be mitigated by agricultural practices [7, 13$15]$.

Long-term year-round monitoring of the reaction of varieties of fruit and berry crops according to physiological (dynamics of photosynthetic activity of leaves according to the level of fluorescence induction of chlorophyll-A in assimilation tissues), biochemical (dynamics of the activity of catalase and peroxidase enzymes), histological (organogenesis, tissue changes) and cytological (changes in cellular structures) indicators made it possible to systematize the most significant weather stressors for plants and to determine the possible reaction of a plant organism to them (Table 1).

Table 1. Parameters of the hydrothermal regime and the main risks for fruit plants

\begin{tabular}{|c|c|c|}
\hline \multirow[b]{2}{*}{ STRESSORS } & \multicolumn{2}{|c|}{$\begin{array}{l}\text { Possible consequences } \\
\end{array}$} \\
\hline & $\begin{array}{l}\text { Internal (at the level of cells, } \\
\text { tissues and metabolic systems) }\end{array}$ & $\begin{array}{c}\text { External (at the level of } \\
\text { organs and plants as a whole) }\end{array}$ \\
\hline $\begin{array}{l}\text { Long-term (more than } 5 \\
\text { days) significant (more than } \\
10^{\circ} \mathrm{C} \text { below average annual } \\
\text { values) decrease in air } \\
\text { temperature in the absence of } \\
\text { snow cover }\end{array}$ & $\begin{array}{l}\text { damage to cell membranes, cell } \\
\text { death, low-temperature tissue } \\
\text { burns, a sharp inhibition of } \\
\text { metabolic processes }\end{array}$ & $\begin{array}{l}\text { low temperature burn of } \\
\text { annual branches }\end{array}$ \\
\hline $\begin{array}{l}\text { Thaws during the period } \\
\text { when plants emerge from } \\
\text { deep dormancy (late } \\
\text { December - February) }\end{array}$ & $\begin{array}{l}\text { activation of cell division, } \\
\text { increased enzymatic activity } \\
\text { during a thaw, increased } \\
\text { vulnerability of plant tissues, } \\
\text { with a sharp drop in temperatur } \\
\text { - damage to cell membranes, } \\
\text { cell death }\end{array}$ & $\begin{array}{l}\text { phenotypic manifestations in } \\
\text { winter are absent, with a } \\
\text { sharp drop in temperatures } \\
\text { after a thaw - death of } \\
\text { generative buds, the risk of a } \\
\text { decrease or loss of yield }\end{array}$ \\
\hline $\begin{array}{l}\text { Extremely low air } \\
\text { temperatures in January- } \\
\text { February or long periods of } \\
\text { low negative temperatures } \\
\text { (below }-25^{\circ} \mathrm{C} \text { ) }\end{array}$ & $\begin{array}{l}\text { damage to conductive tissues, } \\
\text { cells of the cambial layer, } \\
\text { tissues of generative and } \\
\text { vegetative buds }\end{array}$ & $\begin{array}{l}\text { freezing and death of annual } \\
\text { branches, damage of the } \\
\text { forks of perennial branches, } \\
\text { the risk of crop loss }\end{array}$ \\
\hline $\begin{array}{l}\text { High level of insolation in } \\
\text { March }\end{array}$ & $\begin{array}{l}\text { burn damage to tissues of the } \\
\text { cortex parenchyma, cambial } \\
\text { layer, conductive tissues }\end{array}$ & $\begin{array}{l}\text { bark burns on the trunk, burn } \\
\text { injuries in the forks of } \\
\text { skeletal branches, freezing of } \\
\text { annual growth }\end{array}$ \\
\hline $\begin{array}{l}\text { Low (to negative values) air } \\
\text { temperatures in April-May }\end{array}$ & $\begin{array}{l}\text { damage or death of cells in the } \\
\text { most active layers of wood } \\
\text { tissue, damage to cells of } \\
\text { generative and vegetative buds }\end{array}$ & $\begin{array}{l}\text { delay in plant development, } \\
\text { damage to the stigma of the } \\
\text { pistil and (or) its death, } \\
\text { damage and (or) death of } \\
\text { flowers, low degree of } \\
\text { flowering, "ugliness" and } \\
\text { necrotic damage to the leaf } \\
\text { blade, significant weakening } \\
\text { of plants }\end{array}$ \\
\hline
\end{tabular}




\begin{tabular}{|c|c|c|}
\hline $\begin{array}{l}\text { Low average daily air } \\
\text { temperatures }\left(<+15^{\circ} \mathrm{C}\right) \text { in } \\
\text { May - June against the } \\
\text { background of high air } \\
\text { humidity and a large amount } \\
\text { of precipitation (exceeding } \\
\text { the average annual norm }> \\
30 \% \text { ) }\end{array}$ & $\begin{array}{l}\text { low mitotic activity in the cells } \\
\text { of root apexes, low } \\
\text { photosynthetic activity of } \\
\text { chlorophyll-containing tissues, } \\
\text { inhibition of catalase enzyme } \\
\text { activity, high level of } \\
\text { peroxidase enzyme activity }\end{array}$ & $\begin{array}{l}\text { a prolonged flowering } \\
\text { period, a low degree of } \\
\text { fertilization of flowers, low } \\
\text { fruit set, shedding of ovaries, } \\
\text { chlorosis and necrotic } \\
\text { damage to the leaf blade, } \\
\text { massive development of } \\
\text { diseases }\end{array}$ \\
\hline $\begin{array}{l}\text { Drought in July-September } \\
\text { against the background of } \\
\text { high and extremely high air } \\
\text { temperatures }\end{array}$ & $\begin{array}{l}\text { necrosis of fetal tissue cells, lea } \\
\text { blade, low photosynthetic and } \\
\text { catalase activity and abnormally } \\
\text { high peroxidase activity }\end{array}$ & $\begin{array}{l}\text { premature ripening and } \\
\text { massive shedding of fruits, } \\
\text { temperature burns on the } \\
\text { surface of fruits, chlorosis } \\
\text { and low hydration of the leaf } \\
\text { blade, abnormal growth } \\
\text { arrest of annual shoots, } \\
\text { premature leaf fall; mass } \\
\text { distribution of pests; } \\
\text { ugliness, poor quality and } \\
\text { reduced keeping quality of } \\
\text { fruits }\end{array}$ \\
\hline $\begin{array}{l}\text { High level of daily dispersio } \\
\text { of air temperatures }\end{array}$ & $\begin{array}{l}\text { imbalance of all metabolic } \\
\text { processes, abrupt dynamics of } \\
\text { enzymatic and photosynthetic } \\
\text { activity }\end{array}$ & $\begin{array}{l}\text { external symptoms were not } \\
\text { noted }\end{array}$ \\
\hline
\end{tabular}

On the basis of long-term monitoring, systematization, and comparative analysis of the obtained data, it has been established that the main trend in the change in the hydrothermal regime will be destabilized in the territory of the Central Black Earth Region in the coming decades, i.e. the frequency and amplitude of air temperature drops will increase, the number of thaws in January-February will increase, the discrete distribution of precipitation within a year may increase - excessive moisture in June, September and 2-3 decades of FebruaryMarch and aridity in July, August, November, December. This trend determines some changes in the requirements for the varietal composition of cultivated plants suitable for cultivation in the region, especially for perennial fruit crops; in particular, previously suitable highly frost-resistant varieties can be significantly damaged because of a large number of winter thaws and significant changes in daily air temperatures.

The study of the reaction of plants of various horticultural crops (apple, pear, cherry, currant, strawberry) in 1990 - 2020 showed that in recent decades, plants have been under the constant pressure of varying intensity from a number of stressors. This has a significant negative impact on the realization of their productivity potential and the course of all physiological processes in the organism. Perennial fruit crops are particularly affected. Under these conditions, the role of technological factors that can reduce the negative impact of destabilizing weather stressors increases. This is mostly performed in the modern plantations of fruit and berry crops, which use intensive technologies with the ability to regulate water, light, and nutritional regimes. 


\section{References}

1. U Triacca, A. Attanasi, A. Pasini, Environmetrics, 24(4), 260-268 (2013). http://doi.org/10.1002/env.2210

2. S. M. Matveev, A. Milenin, D. Timashuk, J. For. Sci., 64(10), 427-434 (2018) https://doi.org/10.17221/36/2018-JFS

3. M. Sauter, Curr. Opin. Plant Biol., 16(3), 282-286 (2013) http://doi.org/10.1016/j.pbi.2013.03.013

4. A. Matveev, W.F. Vincent, I. Laurion. AGU Abstracts, 12, B43B-0243 (2014) https://ui.adsabs.harvard.edu/abs/2014AGUFM.B43B0243M/abstract

5. A. Pasini, U. Triacca, A. Attanasio, Environ. Res. Lett., 7(3), 034020 (2012) http://doi.org/10.1088/1748-9326/7/3/034020

6. S.M. Matveev, Yu.G. Chendev, A.R. Lupo, J.A. Hubbart, D.A. Timashchuk, Pure Appl. Geophys., 174, 427-443 (2017) http://doi.org/10.1007/s00024-016-1420-y

7. Meteorological data archives 1931-2017 «Tsentral'no-Chernozemnoye UGMS» Tambov and Voronezh

8. E. Tkachev, E. Tsukanova Achievements of Science and Technology of the AIC, 33(2), 17-21 (2019). http://doi.org/10.24411/0235-2451-2019-10205

9. E. Tsukanova, E. Tkachev, IOP.: Earth Environ. Sci., 226, 012034 (2019) http://doi.org/10.1088/1755-1315/226/1/012034

10. C.E. Bita, T. Gerats, Front. Plant sci., 4, 273 (2013) http://doi.org/10.3389/fpls.2013.00273

11. L.V. Grigoreva, O. A. Ershova, Achievements of Science and Technology of the AIC, 30(5), 53-57 (2016) http://agroapk.ru/year-2016-en/108-archive-en/05-2016-en/21262016-05-13-en

12. M. Mizutani, M.M. Kanaoka, Semin. Cell Devel. Biol., 83, 69-77 (2018) http://doi.org/10.1016/j.semcdb.2017.10.029

13. L.V. Grigoreva, T.V. Gorlova, Pomiculture and small fruits culture in Russia, 60, 42-47 (2020) https://doi.org/10.31676/2073-4948-2020-60-42-47

14. L. McAusland, J.A. Atkinson, T. Lawson, E.H. Murchie, Plant Meth., 15, 109 (2019) http://doi.org/10.1186/s13007-019-0485-x

15. V. Oláh, A. Hepp, I. Mészáros. Environ. Exp. Botany, 136, $50-58$ (2017). http://doi.org/10.1016/j.envexpbot.2017.01.007 